varying shades of grey of Chondrites systems which penetrate one another (Simpson, 1 57, p. 492) are to be explained by the varying reaction of slightly different sorts of sediment to calcite segregation, as Dr. Kent requires, then the gradual change from marl to limestone, or vice versa, with which the Chondrites colour changes are associated must also be due to an original difference in the sediment. Thus the lack of sharp boundaries to the limestone beds cannot be evidence of segregation, for it is primary in origin.

Surely the assumption that ordinary sedimentation may not involve graded junctions between limestone and marl is totally unwarranted; and it is difficult even to hold that graded junctions are to be expected with chemical segregation when in fact the concretionary calcareous nodules of the Lower Lias normally show much sharper boundaries than most of the limestones.

So far as I can discover the following summarizes the evidence which supporters of the segregation hypothesis can produce in their favour: (1) occasional fragmented Plagiostoma shells (indicating dilation), (2) thickening of limestone beds around large fossils, and (3) very rare cases in which the attitude of a fossil suggests that limestone surface and bedding surface may not be identical in some places.

I believe (1) and (2) are indeed evidence of segregation, but that such occurrences are confined to a few limestone beds which may be partly concretionary in origin or with which local concretionary centres are associated. The examples of (3) need to be interpreted individually and the evidence they provide at present cannot be claimed to be significant.

\title{
REFERENCE
}

Simpson, S., 1957. On the Trace-Fossil Chondrites. Quart. Journ. Geol. Soc., cxii, 475-499.

\section{Geology Department,}

S. SIMPSON.

THE UNIVERSITY,

BRISTOL, 8.

6th November, 1957.

\section{ASSOCIATION POUR L'ETUDE GEOLOGIQUE DES ZONES PROFONDES DE L'ECORCE TERRESTRE}

SIR,-A field-meeting of the Association in the Scottish Highlands, in September, 1957, was attended by 19 members, representing the following countries: Belgium 3; France 4; Holland 1; Norway 1; Switzerland 2; United Kingdom 3; U.S.S.R. 4; West Germany 1.

From 13 th -17 th September the party was at Newtonmore, Inverness-shire, under the leadership of Professor J. G. C. Anderson, and studied the structure and high-grade metamorphism of Moinian and Dalradian metasediments and the associated migmatite and pegmatite complexes of Strathspey and Loch Laggan. Opportunity was also taken to see post-tectonic intrusions and glacial features.

The members then travelled via Inverness to Balmacara, Ross-shire, where from 17th-21st September, with Dr. J. Sutton and Dr. G. Wilson as leaders, they saw the Loch Alsh fold, the thrust-slices below the Moine Thrust and the folded Moine and Lewisian near Loch Carron and Loch Duich. Particular attention was paid to the successive sets of small structures, and the relations between these and the large folds and thrusts were demonstrated.

On 21st September the party sailed from Kyle of Lochalsh to Mallaig, thence by train to Fort William where the Ben Nevis Ring Complex was examined; the Parallel Roads of Glen Roy were also visited. After the main part of the excursion concluded on 24th September, some members spent a further few days in Ardnamurchan. 
The Association was constituted at the Algiers Congress in 1952. The first field-meeting was held in Norway in 1955. It is proposed to hold the third meeting in 1958 in the Massif Central of France (Directors Professor M. Roques and Professor Lapadu-Hargues).

Information regarding the Association may be obtained from the Secretary, Professor P. Michot, Institut de Géologie Université de Liège, Liège, Belgium, or from the undersigned.

Geology Department,

J. G. C. ANDERSON.

UNIVERSITY COLLEGE,

NEWPORT ROAD,

CARDIFF. 